\title{
CYTOKINE GENES POLYMORPHISMS OF TNF, IFN- $\gamma$ AND IL-12 AS POTENTIAL PREDICTORS IN THE ONSET OF CERVICAL DISEASE ASSOCIATED WITH HR HPV INFECTIONS
}

\author{
Dijana Tasić ${ }^{1}$,Vera Pravica ${ }^{2}$, Maja Ćupić ${ }^{2}$ \\ ${ }^{1}$ Clinic of Gynecology and Obstretics "Narodni Front" \\ ${ }^{2}$ Institute of Microbiology and Immunology, Faculty of Medicine, University of Belgrade, Serbia
}

Abstract

Cervical cancer highly correlates with infection caused by highly oncogenic types of human papillomavirus (high risk HPV, HR HPV), which is one of the most common sexually transmitted pathogens and is a key factor in the development of cervical disease. However, malignant transformation of cells and tumor development are multifactorial and result from the interaction of a large number of factors such as virus genotype and its oncogenic potential, the state of the infected cells, the immune response of the host, as well as many cofactors such as smoking, oral contraceptives, multiparity, early beginning of sexual life, promiscuity, poor socio-economic conditions, poor diet, etc. Recently, an increasing number of studies have focused on examining the role of genetic basis of the pathogenesis and evolution of HR HPV cervical disease. It is known that genes polymorphisms that encode proteins involved in the functioning of Th1 and Th17 cell response may be associated with better or worse prognosis of cervical disease in women with persistent HR HPV infection. Therefore, the single nucleotide polymorphisms (SNP) of the genes encoding TNF, IFN- $\gamma$ and IL- 12 can be considered as putative biomarkers that may have predictive value for the development of the HR HPV cervical carcinoma.

Key words: cervical cancer, HR HPV, gene polymorphism, TNF, IFN- $\gamma$ and IL-12
Sažetak

Karcinom grlića materice visoko korelira sa infekcijom uzrokovanom visoko onkogenim tipovima humanog papiloma virusa (engl. high risk HPV, HR HPV), koji je jedan od najčešće seksualno prenosivih patogena i ključni faktor u nastanku cervikalnog tumora. Ipak, maligna transformacija ćelija i nastanak tumora su multifaktorijalni i rezultat su interakcije velikog broja činilaca kao što su: genotip virusa i njegov onkogeni potencijal, stanje inficirane ćelije, imunskog odgovora domaćina, ali i brojnih kofaktora kao što su pušenje, oralni kontraceptivi, multiparitet, rano stupanje u seksualne odnose, promiskuitet, loši socioekonomski uslovi, ishrana i dr. U novije vreme sve veći broj istraživanja usmeren je na ispitivanje uloge genetske osnove u patogenezi i evoluciji HR HPV cervikalne bolesti. Poznato je da polimorfizmi određenih gena koji kodiraju proteine uključene u funkcionisanje Th1 i Th17 ćelijskog odgovora mogu biti povezani sa boljom ili lošijom prognozom cervikalne bolesti kod žena sa perzistentnom HR HPV infekcijom. Stoga se polimorfizmi pojedinačnih nukleotida (SNP) gena za TNF, IFN- $\gamma$ i IL-12 mogu smatrati biomarkerima koji mogu da imaju prediktivnu ulogu za nastanak HR HPV karcinoma grlića materice.

Ključne reči: karcinom grlića materice, genski polimorfizmi, TNF, IFN- $\gamma$ i IL-12

\section{Introduction}

Cervical cancer is the second most common tumor and certainly the most common genital cancer of women worldwide, especially in developing countries. Each year, about 500.000 women are diagnosed with cervical cancer. The incidence of this tumor at the annual level is different in different geographical regions, ranging from 17.2 to 55 per 100,000 women $[1,2]$. Cervical cancer correlates highly with infection caused by highly oncogenic types of human papillomavirus (high risk HPV, HR HPV), which is one of the most common sexually transmitted pathogens $[3,4]$. Since the early eighties of the twentieth century, when Harald zur Hausen proved highly oncogenic HPV types 16 and 18 in cervical cancer cells, it was shown that HPV infection is a key factor in its emergence. However, in a high percentage (> 80\%) of women infection with HR HPV types leads to spontaneous regression and elimination of the virus within two years of contact with the virus. In a minority of cases persistent infection is established from which $25 \%$ of infected women develop cervical intraepithelial neoplasia 
in the first degree (CIN I), with further progression (CIN II / III). In $10 \%$ of patients, or $1 \%$ of infected women over a number of years, cervical cancer will be developed [5].

Malignant transformation of cells and tumor development are multifactorial and result from the interaction of many factors such as genotype of the virus and its oncogenic potential, the state of the infected cells, the immune response of the host, but also many cofactors such as smoking, oral contraceptives, multiparity, early beginning of sexual life, promiscuity, poor socio-economic conditions, poor diet, etc.

\section{Relationship between HR HPV E6/E7 on- coproteins and activation of the network of cell signaling pathways}

HPV early genes E6 and E7 are tumor-associated genes responsible for viral oncogenesis and their expression is under the control of the E2 gene. With the integration of viral genome into the cell chromosome during the persistent HR HPV infection, the expression of E2 gene is reduced, thereby losing control over the E6/E7 oncogenes, which results in their over expression. Oncoproteins of these genes inactivate tumor-suppressor proteins p53 and $\mathrm{Rb}$, whose role in the normal conditions is to maintain the cell cycle under control and when it is necessary to "introduce" the cell to programmed cell death or apoptosis [6]. In recent years, it is believed that

the activation of the network of cell signaling pathways is the critical event in the initiation of malignant transformation of cells during the persistent infection caused by highly oncogenic types of HPV. In order to achieve its persistence, HPV avoids the immune response by interfering with signaling pathways of innate immunity [7]. JAK-STAT signaling pathway is activated by interferons, whose level in the cell during the early viral infection is significantly increased. E6/E7 proteins perform selective inhibition of STAT-gene regulatory proteins which continued suppression is required for HPV replication [8].An increased activity of NF-kappaB latent gene regulatory protein was detected in many carcinomas. Initially, E6 and E7 oncogenes suppress NF-kap$\mathrm{paB}$ in order to avoid the innate immune response and achieve the persistent infection. By establishing the persistence and chronic inflammation, they increase the activity of NF-kappaB signaling pathway that contributes to the development of cancer $[9,10]$.

Also, the E6 and E7 oncogenes increases the transcription of the hTERT-human telomerase reverse transcriptase that is catalytic subunit of telomerase, enhancing and stabilizing the activity of this enzyme, resulting in immortalization of the cells $[11,12]$.
E5 is also an HPV oncogene that in the early stages of carcinogenesis has an effect on increasing the number of receptors for epidermal growth factor (EGFR - epidermal growth factor receptors) on the surface of keratinocytes and enhances their activity even in the absence of EGF. E5 enhances Ras and MAPK signaling pathways via EGF, leading to their continuous activation. MAPK leads to constitutive activation of Myc regulatory gene, which leads to transformation, hyperproliferation and carcinogenesis [11].

\section{Cytokine gene polymorphisms as biomark- ers associated with HR HPV cervical disease}

In recent years considerable research has focused on examination of the role of genetic basis in the development of HPV associated cervical cancer. Previous studies have shown that the occurrence of cervical cancer represents an interaction of multiple genes and environmental factors. Although thanks to advances in modern technology to examine gene polymorphisms of the entire genome (genome-wide association studies, GWAS) the number of genes whose individual alleles are associated with predisposition to the development of this cancer have been discovered, there are still contradictory data on polymorphisms in genes that encode proteins involved in the functioning of Th1 and Th17 cell response. This also applies to data on the role of proinflammatory mediators important in the pathogenesis of persistent HR HPV infections in the occurrence of cervical cancer, by different research teams, in different ethnic populations from different geographic areas [13]. In recent years, an increasing role is proposed to a genetic predisposition in the development of cervical cancer in women with HR HPV infection. Single nucleotide polymorphisms (SNP) in the genes that encode the relevant proinflammatory cytokines such as TNF, IFN- $\gamma$ and IL-12, are becoming very important genetic markers to assess the risk for development of cervical cancer associated with HR HPV.

It is now known that the SNP at the position -308 in the promoter region of TNF gene (rs1800629) G/A, is highly correlated with CIN I associated with HR HPV. TNF is one of the most important proinflammatory cytokines, which plays an important role in inflammatory diseases. It is believed that the $\mathrm{A}$ allele at position - 308 TNF gene, which is a high secretory TNF phenotype, could have a powerful influence on the development of HR HPV cervical cancer [14]. The above-mentioned TNF -308 G/A polymorphism, which may result in a high production of TNF, favors the activity of cyclin dependent kinase (CDK) that amplifies the mRNA expression of E6/E7 of the HPV-immortalized keratinocytes. Also, 
it has been shown that TNF stimulates the transcription of the EGFR, which stimulates cell proliferation and tumorgenesis. Many studies show that in women with CIN, the level of TNF in serum is significantly higher than in healthy women, as well as that GA genotype in -308 locus of TNF gene as compared to GG and AA genotypes, has a higher risk for development of cervical tumor in HR HPV positive women $[15,16]$.

IFN- $\gamma$ is one of the most important Th1 immune modulators with anti-viral and anti-tumor role. SNP at the position $+874 \mathrm{~T} / \mathrm{A}$ (rs62559044) located in the first intron of IFN- $\gamma$ gene is associated with increased production of IFN- $\gamma$ and efficient defense against HPV infection, while its low level, which is present in the cervical cancer, is associated with poor prognosis. The DNA sequence containing the $+874 \mathrm{~T}$ allele has binding site for NF-kappaB transcription factor [17,18]. A large number of articles shows that the dominance of the $\mathrm{T}$ allele correlates with over expression of IFN- $\gamma$ and reduces the risk of cervical cancer, while the low secretory +874 IFN- $\gamma$ AA genotype, is associated with the high risk for developing HR HPV cervical tumor [3,19].

Numerous studies have shown that IL-12 leads to an efficient destruction of cancer cells. IL-12 is a heterodimer composed of two subunits, p35 (IL-12A) and p40 (IL-12B). It is synthesized by dendritic cells, macrophages and B-lymphoid cells. Inheritance of IL-12A and IL-12B gene variants, especially functional SNP, drastically changes its expression, as well as other cytokines whose function is under the influence of IL-12 [20]. IL-12 stimulates the production of IFN- $\gamma$ by signaling molecular cascade, at the same time it inhibits IL-4, which suppresses the synthesis of IFN- $\gamma$, and it encourages protective Th1 immune response [20]. SNP at position $+1188 \mathrm{~A}$ / $\mathrm{C}$ in the 3'UTR region of the IL-12B gene ( $\mathrm{rs3212227)}$ is associated with a predisposition to cervical cancer in women with HR HPV. Investigation shows that the AA genotype is associated with progression of HR HPV lesions in cervical cancer [19].

\section{Conclusion}

Polymorphisms of certain proinflammatory cytokines could be the biomarkers that indicate a higher risk for development of cervical cancer in women with HR HPV infection and potentially discriminate a genotype that favors or has a protective role in the development of HR HPV cervical disease. Therefore, HPV genotype, as well as relevant cytokine gene polymorphisms, can now be considered as probable predictors that allow early prognosis, individual treatment approach and the selection of appropriate therapeutic procedures in female patients with persistent HR HPV cervical disease.

\section{References}

1. Pisani P, Bray F, Parkin DM. Estimates of the world-wide prevalence of cancer for 25 sites in the adult population. Int J Cancer 2002; 97: 72-81.

2. Shanta V, Krishnamurthi S, Gajalakshmi CK, Swaminathan R, Ravichandran K.Epidemiology of cancer of the cervix: global and national perspective. J Indian Med Assoc 2000; 98:49-52.

3. Gangwar R, Pandey S, Mittala RD. Association of interferon-g $+874 \mathrm{~A}$ polymorphism with the risk of developing cervical cancer in north-Indian population. BJOG 2009;116: 1671-1677.

4. Sankaranarayanan R, Nene BM, Dinshaw K, Rajkumar R, Shastri S, Wesley R, et al. Early detection of cervical cancer with visual inspection methods: a summary of completed and on-going studies in India. Salud Publica Mex 2003; 45: 399-407.

5. Zur Hausen H. Papillomaviruses and cancer: from basic studies to clinical application. Nat Rev Cancer 2002; 2: 342-350.

6. Raybould R, Fiander A, Hibbitts S. Human Papillomavirus Integration and its Role in Cervical Malignant Progression. The Open Clinical Cancer Journal, 2011; 5: 1-7.

7. Tummers B, Van Der Burg SH.High-Risk Human Papillomavirus Targets Crossroads in Immune Signaling. Viruses 2015; 7: 2485-2506.

8. Hong S, Mehta KP, Laimonis AL. Suppression of STAT-1 Expression by Human Papillomaviruses Is Necessary for Differentiation-Dependent Genome Amplification and Plasmid Maintenance. J Virol 2011; 85: 9486-9494.

9. Vandermark ER, Deluca KA, Gardner CR, Marker DF, Schreiner CN, Strickland DA, et al. Human papillomavirus type $16 \mathrm{E} 6$ and $\mathrm{E} 7$ proteins alter NF-kB in cultured cervical epithelial cells and inhibition of NF-kB promotes cell growth and immortalization. Virology 2012; 425: 53-60.

10. Nees M, Geoghegan JM, Hyman T, Frank S, Miller L, Woodworth CD. Papillomavirus Type 16 Oncogenes Downregulate Expression of Interferon-Responsive Genes and Upregulate Proliferation-Associated and NF-kB- Responsive Genes in Cervical Keratinocytes . J Virol 2001; 75: 4283-4296.

11. Gu Z, Matlashewski G. Effect of Human Papillomavirus Type 16 Oncogenes on MAP Kinase Activity. J Virol 1995; 69: 8051-8056.

12. Wang YW, Chang HS, Lin CH, Winston CY. HPV-18 E7 conjugates to $\mathrm{c}-\mathrm{Myc}$ and mediates its transcriptional activity. Int J Biochem Cell Biol. 2007; 39: 402-412.

13. Hirschhorn JM, Daly J. Genome-wide association studies for common diseases and complex traits. Nat Rev Genet 2005, 6: 95 - 108.

14. Wilson AG, Di Giovine FS, Blakemore AI, Duff GW. Single base polymorphism in the human tumour necrosis factor a (TNF a) gene detectable by NcoI restriction of PCR product. Hum Mol Genet 1992;1: 353.

15. Kirkpatrick A, Bidwell J, van den Brule AJC, Meijer CJ, Pawade J, Glew S. TNFa polymorphism frequencies in HPV-associated cervical dysplasia. Gynecol Oncol 2004; 92: 675-679. 
16. Wang L, Ma K, Wang Z, Mou Y, Ma L, Guo Y. Association between tumor necrosis factor alpha rs 1800629 polymorphism and risk of cervical cancer. Int J Clin Exp Med 2015; 8: 2108-2117.

17. Liu N, Song Y, Shi W. IFN- $\gamma+874$ T/A polymorphisms contributes to cervical cancer susceptibility: a meta-analysis. Int J Clin Exp Med 2015; 8: 4008-4015.

18. Pravica V, Perrey C, Stevens A, Lee JH, Hutchinson IV. A single nucleotide polymorphism in the first intron of the human IFN-gamma gene: absolute correlation with a polymorphic CA microsatellite marker of high IFN-g production. Hum Immunol 2000; 61: 863-866.

19. de Carvalho VCV, de Macedo JL, de Lima CAD, de Lima MCG, Hera' clio SA, Amorim M , et al. IFN-gamma and IL-12B polymorphisms in women with cervical intraepithellial neoplasia caused by human papillomavirus. Mol Biol Rep 2012; 39:7627-7634.

20. Chang SW, Xu GQ, Fan YL. Association of interleukin-12 gene polymorphisms with cancer susceptibility: a meta-analysis. Int J Clin Exp Med 2015; 8: 5317-5322 